BULLETIN Bulletin hispanique

HISPANIQUE Université Michel de Montaigne Bordeaux

121-2 | 2019

Representaciones de autor (XV-XIX). Retratos, biografías, polémicas

\title{
Samuel Rodríguez, Universo femenino y mal. Estudio crítico de la narrativa de Espido Freire
}

Madrid, Universidad Autónoma de Madrid, 2019

\section{Ángel García Galiano}

\section{OpenEdition \\ Journals}

\section{Edición electrónica}

URL: https://journals.openedition.org/bulletinhispanique/9773

DOI: 10.4000/bulletinhispanique.9773

ISSN: 1775-3821

Editor

Presses universitaires de Bordeaux

Edición impresa

Fecha de publicación: 18 diciembre 2019

Paginación: 763-764

ISBN: 979-10-300-0507-3

ISSN: 0007-4640

\section{Referencia electrónica}

Ángel García Galiano, «Samuel Rodríguez, Universo femenino y mal. Estudio crítico de la narrativa de Espido Freire», Bulletin hispanique [En línea], 121-2 | 2019, Publicado el 10 diciembre 2019, consultado el 02 enero 2023. URL: http://journals.openedition.org/bulletinhispanique/9773 ; DOI: https://doi.org/ 10.4000/bulletinhispanique.9773

Este documento fue generado automáticamente el 2 enero 2023.

All rights reserved 


\title{
Samuel Rodríguez, Universo femenino y mal. Estudio crítico de la narrativa de
} Espido Freire

\author{
Madrid, Universidad Autónoma de Madrid, 2019
}

\author{
Ángel García Galiano
}

\section{REFERENCIA}

Samuel Rodríguez, Universo femenino y mal. Estudio crítico de la narrativa de Espido Freire. Madrid, Universidad Autónoma de Madrid, 2019, 328 pp.

1 Este estupendo ensayo sobre la obra novelística de la escritora española Espido Freire (1974) presenta la peculiaridad, muy destacable, de ser uno de los pocos trabajos serios y rigurosos que acometen el estudio de esta fecunda y aun joven novelista, aunque muy consagrada por el público, los premios y cierta crítica. Escritora prolífica que cuenta ya con una muy considerable obra ensayística y narrativa, dividida esta, a su vez, entre su producción novelística, la que aquí nos compete y la cuentística de la que, por cierto, Samuel Rodríguez se hace eco cada vez que lo considera oportuno para profundizar en un tema o subrayar alguna característica importante.

El propósito del autor consiste en analizar las siete novelas de la autora desde el punto de vista de su relación con el mal en el contexto del universo femenino. Para ello, divide el ensayo en dos partes, un primer ámbito teórico de reflexión en que analiza el universo femenino de Espido, sobre todo en lo atingente a la construcción e interpretación de los personajes y el problema del mal como motor de su producción narrativa.

El primer capítulo aborda el universo femenino de la autora, para ello, elude enzarzarse, con buen criterio, en la disquisición sobre la existencia, o no, de una «literatura femenina», prefiere, por el contrario, hablar de la universalidad andrógina literaria de Espido Freire. El análisis acomete todos los elementos capitales a la hora de 
configurar el universo narrativo de Espido Freire, a saber: motivos y temas, tramas y tratamiento del tiempo, voces narrativas y perspectivas, atmósfera, creación de espacios y, dentro de ellos, prefiguración de los personajes. Muy útil y pertinente nos ha parecido la subcategorización que hace de los mismos, al dividir a estas en mujer pseudo fatal, frágil, malvada y víctima/verdugo. Resulta también de gran interés cómo el autor apela a la música -siendo él mismo músico- como uno de los elementos estructurantes y temáticos de la narrativa toda de Espido Freire.

El segundo capítulo de esta primera parte se dedica a analizar filosóficamente el problema del mal, sus orígenes, su ontología y una serie de consideraciones, muy bien traídas, sobre la contingencia, la angustia, la muerte, la alteridad, la violencia y los cuentos de hadas. Para ello aborda el mal como sustancia universal, la muerte como continuación de la existencia, el mal en la alteridad y, sobre todo, la mujer como instrumento de proyección del mal y del sujeto contingente. Muy interesante el tratamiento de la violencia en el universo espidiano, así como el mal de injusticia y la subversión del orden.

5 Me parece muy adecuada la mención que hace a la tragedia y cómo, para lograrla, Espido Freire propende a la mitificación de espacios y personajes (p. 111 y ss.).

6 La segunda parte del trabajo consiste en el análisis propiamente dicho de las novelas de Espido Freire. Desde la primera y fundacional Irlanda (1998), que el autor califica como un «debut perverso», hasta la última publicada en el momento de elaboración del libro, La flor del Norte (2011).

7 Quiero destacar el riguroso uso de una metodología sincrética, en la que se apela a la narratología o la psicocrítica allí donde al autor le parecen pertinentes unos u otros métodos de análisis. La circularidad que reconoce en sus creaciones tiene que ver, precisamente, con la construcción de unos espacios físicos que, al cabo, podrían ser mentales. De esta forma, la narrativa de Espido Freire esboza una línea en la que prima el mito frente a la historia y el tiempo circular frente al lineal. Todo ello coadyuva de manera decisiva a conseguir ciertas atmósferas trágicas y ciertos mundos de pesadilla, de condena de los personajes.

Quiero resaltar el buen tono formal con que se ha construido el ensayo, la sensibilidad musical y literaria con que se acometen ciertos aspectos de las obras y la mirada nueva, original y limpia, con que el autor elabora, sin renunciar al rigor académico ni la precisión, todos estos análisis.

9 Como decía, la bibliografía es adecuada y su uso muy pertinente y preciso, la metodología, proteica, en busca de adaptarse a las necesidades elucidatorias del texto y no al revés, intentando encajar con el fórceps de la crítica el vuelo creativo del autor. A la originalidad del tema elegido, se ha de sumar la conveniencia de ofrecer un panorama amplio y riguroso de la obra de una autora muy aplaudida por el público, pero algo desatendida en los predios académicos.

10 En definitiva, se trata de un trabajo excelente, que aborda con valentía análisis muy complejos y sale airoso de cada una de sus acometidas, con solvencia y elegancia formal, pues es de subrayar que el libro está muy bien escrito. 


\section{AUTORES}

ÁNGEL GARCÍA GALIANO

Universidad Complutense de Madrid 